\title{
Preschool teachers' competencies for inclusive practice and partnership with parents - experiences from Croatia
}

\author{
Anka Jurčević Lozančić ${ }^{1}$, Ivana Golik Homolak ${ }^{2}$ \\ ${ }^{1}$ Faculty of Teacher Education, University of Zagreb, Croatia \\ ${ }^{2}$ Faculty of Teacher Education, University of Zagreb, Croatia
}

\begin{abstract}
The competencies preschool teachers need to acquire and the skills they need to develop have changed in the last few decades, turning them into professions which require continuous critical reflections, objective insights and acceptance of one's own role in the inclusive practice. Preschool teachers are required to understand and know how to establish a close, trusting and accepting relationship with parents. They are also expected to be able to balance expectations, norms and requirements they put on themselves and parents. In order to achieve this, they should use the contemporary educational partnership procedures in their immediate inclusive practice. Given all that, the competencies for inclusive practice actually represent a continuous process which implies the ability to contribute to and build the corpus of the existing knowledge, as well as to develop the practical and reflective skills and professional attitudes. The aim of the current paper is to analyze the preschool teachers' professional competencies for inclusive practices and partnerships with parents in the Croatian preschool facilities. With the help of a semi-structured interview, the examinees gave their opinions on the inclusive practice and partnership with parents, the type of cooperation with parents, and the way of acquiring competencies for maintaining partnership with parents.
\end{abstract}

Keywords: social inclusion, dialogue, difficulties and support

\footnotetext{
${ }^{1}$ Faculty of Teacher Education, University of Zagreb, Croatia
} 


\section{LCNAEDUCATION \\ 27-29 March, 2020 \\ Oxford, United Kingdom}

\section{Introduction}

The primary role of a preschool institution is to provide quality care, upbringing and education for children from six months to the age when they start going to school, quality conditions for optimal satisfaction of children's needs, and a stimulating educational context for the development of their potentials, as well as to develop and promote a partnership relationship with their parents. In an institutional context, the partnership between parents and preschool teachers is an important factor in the child's development because it enables the child to feel accepted, safe, content and happy in an environment that stimulates the development of all his or her capabilities, in accordance with his needs, abilities and specificities. Various programs and social activities, such as websites, network communication, interactive workshops, interactive parent-teacher conferences, parental involvement in kindergarten curricula, etc. are designed to build partnerships between families and educational institutions (Lee and Bowen, 2006). According to the available literature in this field, it is evident that many other forms of cooperation are intended to support the family in order to ensure the child's development and advancement.

However, despite the awareness of the importance of partnerships, there are numerous examples of different doubtful situations because they are not addressed in accordance with the principles of desirable practice with parents. A failed partnership is marked by different barriers, such as a lack of time, lack of self-confidence and competency, mismatch, negative experiences, unrealistic expectations and the like. A lack of trust results in possible negative feelings regarding the real or imaginary obstacles to preschool teachers and parents' identity, power, position. Parenting children with special needs raises many questions and dilemmas for the family. Therefore, in a partnership, the preschool teacher should be able to assume ethical responsibility for respect and acceptance, equality, active listening, a two-way communication, appropriate and coordinated educational action towards the child with the aim of the child's long-term well-being. Partnership with the child's family is one of the fundamental principles as stated in the document Nacionalni kurikulum za rani i predškolski odgoj $i$ obrazovanje ${ }^{2}$ (2014), which emphasizes the need to affirm the role of a quality and stimulating relationship between parents and preschool teachers as the equal partners in education. Thus, parents become the equal participants in the educational process and actively participate in the child's upbringing. The relationship of passivity disappears; parents contribute with their own knowledge and skills to improving the institution's work quality, so that the even distribution of power is then possible. According to Ljubetic (2014), partnership implies a continuous awareness of the importance of a better understanding of partners in the relationship, the communication processes that take place between them, the often untapped potentials they have, and the ultimate benefits of having a quality partnership with children, preschool teachers and parents.

Research conducted worldwide (Acedo, 2008; Avramidis, Bayliss and Burden, 2000; Desforges and Abouchaar, 2003; Mitchel and Hegde, 2007; Whalley, 2007) and in the Croatian context (Jurčević Lozančić, Basta, Šerbetar, 2019; Maleš, Kušević, Širanović, 2014; Visković and Višnjić Jevtić, 2017) highlight a positive correlation between the positive child outcomes and the frequency of active parental involvement. The partnership aims to achieve

\footnotetext{
${ }^{2}$ The National Curriculum for Early and Preschool Education.
} 


\section{$2^{\text {nd }}$ International Conference on \\ New Approaches in EDUCATION}

\section{LCNAEDUCATION \\ 27-29 March, 2020 \\ Oxford, United Kingdom}

continuity in education that ensures the effective interconnection of all participants, which is crucial for their further development, as well as for the development of a child-focused curriculum and a preschool curriculum.

\section{Partnership with the family - a goal to aim at and preschool teachers' competencies}

From the first moment parents enroll a child in kindergarten, the parent-preschool teacher relationship becomes extremely important. In order for children to explore and build on their knowledge and cognition, they need to have a sense of security and support in their environment. An important factor in building a sense of security is the preschool teacher, and the connection between the preschool teacher and the child will be built faster if the child witnesses the calm and relaxed parent who brings him/her to kindergarten, and if he/she witnesses the relationship of respect and reciprocal communication in meetings shared everyday (Deslandes, Barma and Morin, 2015). There are several generally accepted models of partnership with parents. For the purposes of this paper, we will single out the often cited Epstein (2011) model that interprets parental involvement in the following categories: basic parenting responsibilities, basic institution responsibilities, parental involvement through volunteerism and group assistance, active parental involvement in educational activities in the family home (coordinated by the preschool teacher) and parental involvement in decisionmaking. Furthermore, the PPEL (Parents as Partners in Early Learning) model (DCSF, 2008) begins with communication that includes daily exchange of information on plans and events. Due to the day-to-day information on planned activities and their implementation, the parents' interest grows and the preschool teacher can engage them further by explaining and inquiring about activities that the child enjoys in the home environment, so that he or she can use them when planning further incentives and activities in the kindergarten. When the level of engagement has been reached, there is a change in parents and preschool teachers' behavior. The parent will feel empowered in his/her parenting role and the preschool teacher will perceive the parent as a partner in the child's learning. The dialogue at the achieved level needs to be constantly maintained and encouraged in order to successfully reach the highest level of partnership, which is inclusion. In our experience, practice itself can have the greatest influence on changing practitioners' personal views, but only if practitioners explore it, get to know and understand it better and, based on all of those, change and develop it.

When assessing the real, not the declarative level of partnership with parents, preschool teachers should be aware of their explicit pedagogy and assess how much they are really inclusive, i.e. how much and in what way they encourage cooperation with parents. Surely, it is quite possible for preschool teachers to establish partnership relationships with parents on different levels based on how well they know parents, if they feel relaxed in communication with them and so on. However, it is difficult for the preschool teacher to become aware of the difference between his/her implicit pedagogy (the way they think they communicate with parents) and his/her actual communication (explicit pedagogy). Co-experts should give the preschool teacher an external, neutral point of view on his/her communication. When establishing a relationship with the preschool teacher, parents expect trust, openness and 
tolerance (Wheeler and Connor, 2006), as well as the understanding of the difficulties parenting poses, support, patience, and the possibility of exchanging information (Epstein, 2011). Research on partnership (Keyser, 2006; Preston, 2009; Winton, Brotherson and Summers, 2008) shows that parental involvement has a positive effect on the partnership between parents and preschool teachers. Research results have shown that parental involvement is interrelated with the parent's socio-economic status, sex (Lee and Bowen, 2006; Ressler, Smith and Crosnoe, 2017), health and attitudes on his/her own competence in the parenting role (Desforges, 2003). Research has confirmed the prognostic importance of attitudes for social behavior. In other words, the person will behave in accordance with his/her attitudes. Given all that, determining the specific preschool teacher's attitudes towards cooperation with parents is extremely important as preschool teachers are immediate creators, organizers and implementers of the work program they assess, change and develop (Jurčević Lozančić, 2016; Keyser, 2006; Preston, 2011). Various experts and scientific publications by Acedo, (2008); Cankar, Deutsch and Kolar, (2009); Deslandes, Barma and Morin (2015); Ward, (2013), and others indicate the presence of traditional forms of cooperation between preschool teachers and parents, and the most common ones are individual talks, parentteacher conferences and asking for or gathering materials, as well as a one-way communication via phone, email or aforementioned newsletters. Parents' trust in preschool teachers is related to the type and frequency of their involvement (Dunlap and Fox, 2007), as well as to the complementarity of goals and expectations for the child (Hornby, 2011). According to Özyürek (2012), parents' trust in the institution (kindergarten) depends on their belief that the kindergarten and preschool teachers will fulfil their expectations, and treat them objectively, openly and as someone they can rely on. Because of the lack of research relevant for the Croatian context, the aim of the research conducted by Jurčević Lozančić et al. (2019) was to determine the frequency and parent's contentment with different forms of cooperation and their interrelatedness. The obtained results indicate parents' perception of the achieved quality cooperation with preschool teachers and their openness to the preschool teacher in supporting parenting. Parents assess that their needs for cooperation are more satisfied in the forms of activities in which they participate more often.

Quality partnership between preschool teachers and parents is unquestionable, so the preschool teacher is expected to have developed competencies necessary for building and furthering a quality partnership with parents. However, as mentioned in the introduction here, cooperation with parents is characterized by numerous challenges, so that some preschool teachers are not sure whether they should involve parents in the curriculum contents because they believe they are experts, while parents are not educated enough (Ranson, Martin and Vincent, 2004). They also warn us about the lack of time for cooperation. By problematizing the phenomenon of stress, when working as a preschool teacher, Živčić-Bečirević and Smojver-Ažić (2005) conducted a research with the aim of constructing a stress scale for preschool teachers in kindergartens. The scale would also serve for enquiring into the differences in the expressiveness of certain dimensions of stress sources with regard to preschool teachers' years of work experience. The results of the conducted research show that the category 'partnership with parents' is the second stress source for preschool teachers, also that the stress source is continuous and does not diminish despite preschool teachers' years of work experience. The partnership between preschool teachers and parents is conditioned by preschool teachers' knowledge, skills and beliefs acquired during their professional education 
and continuous professional development further on, as well as by all of parents' endeavors to perfect their parental competencies, with the help of the preschool teacher (Maleš et al., 2014). The preschool teacher's competency for cooperation with parents allows for establishing and maintaining satisfactory professional and cooperative relationships with the parents of children enrolled in a preschool institution in order to increase the educational wellbeing of early childhood and preschool children.

\section{Inclusive practice and partnership with parents}

The education system in the Republic of Croatia implements educational inclusion through defined programs that are aimed at providing support for learning and teaching all children, as well as at accepting differences. Including the children with disabilities in regular educational groups has a significant positive effect on the development of all children, and stimulates the psychosocial, cognitive and emotional development (Jurčević Lozančić, 2016). Research also shows that inclusion reduces differences in the educational achievements of children from poorer families, children with disabilities, at-risk children, as well as minority children. The relationship between parents and the preschool teacher is a fundamental factor of quality inclusion, and has a direct effect on the child's contentment with achieved results and that of their parents and preschool teachers. Quality inclusion is recognized by the feeling of belonging, positive interaction with peers, development and learning of children in the sense of achieving their full potential (Odom, Buysse and Soukakou, 2011). A parent is an irreplaceable source of information about the child, family circumstances, parents' characteristics and their relationship with the child. Based on the family circumstances and parents' characteristics, appropriate forms and contents should be planned for cooperation adjusted to the specificities of the family context. The partnership between the preschool teacher and parents develops depending on parents and preschool teachers' attitudes towards each other, and on the compatibility of shared goals related to the child's progress (McWayne and Owsianik, 2004). A positive relationship will be built if both parents and preschool teachers share responsibility and expectations, and if preschool teachers appropriately meet parents' needs and priorities (Preston, 2011). Empowered by preschool teachers' cooperation and support, the parents of children with disabilities feel more competent and confident when they can be involved in their child's development. Through such cooperation, preschool teachers get a wider sense of the child's abilities and a better understanding of the child's specific needs. Due to the good relationship preschool teachers have with parents, their relationship with the child also becomes better. It is important that both preschool teachers and parents invest a lot of trust, openness, tolerance into the mutual cooperation, agree on educational influences and solve problems in the child's development and education together (Whalley, 2007).

The parents of children with disabilities are exposed to various risks due to different needs and constant exposure to stress (financial and psychosocial), as well as due to a more difficult adaptation of their children and other people's attitudes towards them and their child (Özyürek, 2012). According to Mitchel and Hedge (2007), preschool teachers face with a lack of specific knowledge about the strategies and techniques used in inclusion, and not enough experience due to which they have a hard time meeting the needs of children with disabilities or their parents. Also, a problem might occur if the preschool teacher's goals for the child are different than those of parents, and if preschool teachers have a different perception of 


\section{LICNAEDUCATION

parents' efficacy, as well as if parents have unreal expectations from the preschool teacher and the kindergarten. Contemporary parenting is related to various challenges, and the preschool teachers' professional task is to support parents through different forms of cooperation (Ward, 2013). The need for developing preschool teacher's competencies in supporting and advising parents for the child's well-being is extremely significant, especially in inclusive education.

In an inclusive environment, where the children with different abilities and learning capabilities can be found, the preschool teacher is expected to provide every child with equal opportunities, so that they can develop their full potential and teach with respect to individual educational needs. The flexibility and diversity of cooperation with parents, suited to their own different needs, are an extremely important area of the preschool teacher's inclusive work. Having in mind the research results and the theoretical concepts on which they are based, Jurčević Lozančić et al. (2019) conclude that preschool teachers' positive attitudes in establishing cooperation with parents are an imperative for their professional work.

To understand the cooperation or partnership with parents and the preschool institution, we believe it is important to know the perspective of every involved party, which is why this paper perceives partnership from the preschool teacher's perspective. This research is a constituent part of the scientific project, titled 'Researching inclusive practice and partnership with parents from the preschool teacher's perspective,' which has been conducted at the Faculty of Teacher Education, the University of Zagreb, since 2019. For the purposes of this paper, a part of the research will be presented here. Preschool teachers $(\mathrm{N}=126)$ participated and, in a semi-structured interview, expressed their opinions on inclusive practice and cooperation with parents, as well as on the ways of acquiring competencies for their cooperation with parents. The sample was based on the convenience principle and comprised of preschool teachers who, we believed, will provide useful knowledge and insight into some better understanding of this research topic.

Given the fact that this paper's aim is to analyse preschool teachers' professional competences for the inclusive practice and partnership with parents in the Croatian preschool institutions, two thematic areas have been defined for this research purposes in advance: difficulties in partnership with parents, and suggestions for improving cooperation with parents. The emphasis is on gaining a holistic description of certain situations or activities related to cooperation with parents. The analysis of individual answers to open-ended questions is presented below.

In their views on difficulties in partnership with parents, the preschool teachers most often mentioned the parental disinterest and/or negating the child's problems or disabilities. They reported the irregular communication with parents and put an emphasis on a problem of too busy parents. The preschool teachers mentioned the difficulties in communication with parents since not all parents had the same expectations, and they also enumerated various examples from practice, pointing out insecurities in finding an adequate approach to parents. Moreover, the preschool teachers emphasized that parents overprotect their children, negate information relating to difficulties in working with the child, and do not trust institutions. The preschool teachers warned about the parent's lack of information about the child, refusing or withholding information. Some preschool teachers had specific remarks and pointed to a lack of competence for partnership with parents. That issue was also mentioned in the following 
preschool teacher's statement: I establish connections with the parents who are more interested, I do not know how to connect with disinterested parents. A part of the quote also refers to insecurity in deciding on the adequate forms of cooperation which would be suitable for each parent. The preschool teachers pointed out that they did not feel competent enough to work with parents because, during their initial high education, they had not acquired competencies necessary for working with parents. To be more specific, one of them stated: I do not have enough knowledge and skills for the pedagogical work with the parents of the children with disabilities.

The majority of preschool teachers mentioned the need for empowering parents, as well as for educating preschool teachers, which would, in their opinion, make establishing quality cooperation possible and ensure the successful inclusive practice. Earlier research worldwide show that preschool teachers do not feel competent enough to implement inclusive practice, so the need for additional training and development is emphasized (Acedo, 2008). Similar research conducted in Croatia also confirms that the existing initial education and further professional education of preschool teachers are not sufficient for developing the preschool teachers' professional competencies (Visković and Višnjić Jevtić, 2017).

To summarize, it is evident that the relationship between parents and preschool teachers comes across structural problems, such as a lack and limitedness of time for mutual communication and cooperation, a lack of communication, work overload and overprotectiveness of the child, a lack of knowledge and skills for partnership development. Aforementioned preschool teachers' statements express that some parents of the children with disabilities do not understand that they also have to be involved and participate in working with professional preschool teachers, which is why it is necessary to encourage them since parents struggle with accepting their child's disability. A focus on the child, his/her achievements in educational community, his/her well-being and progress diminishes possible parents' insecurities.

The second category of questions encompassed suggestions for improving cooperation with parents. The preschool teacher's responses were diverse, but the majority of them emphasized: empowerment through education, individual approach and honest communication, a more open and engaged relationship by both parties (parents and preschool teachers), acceptance, openness, expertise, availability. The preschool teachers' responses, pointing out that the primary goal and purpose of work is to support parents and the child, are encouraging. More specifically, as they often emphasized in their responses: partnership is important in order for the parent to feel safe, and the child to feel accepted. In order for the cooperation to lead to a set goal, parents' intrinsic motivation is surely needed, which is confirmed by one of the preschool teachers' declaration: I am truly motivated to help the child and the parent; it's a special feeling when you find out you succeeded in doing that. By summarizing the preschool teachers' thoughts, their positive attitude towards partnership with parents is noticeable. For example, when describing their experiences in cooperating with parents, the preschool teachers used the terms like: empathy, honesty, support, understanding, synergy, professionalism, dialogue. The following item pointed out by the preschool teachers is using social media which, in their opinion, significantly contribute to developing and maintaining partnership with parents, and are effective even in the kindergarten context: Facebook, Twitter, Instagram, YouTube, smartphone apps and the like. This preschool teacher's statement confirms that: I believe communication would be easier 


\section{$2^{\text {nd }}$ International Conference on \\ New Approaches in EDUCATION}

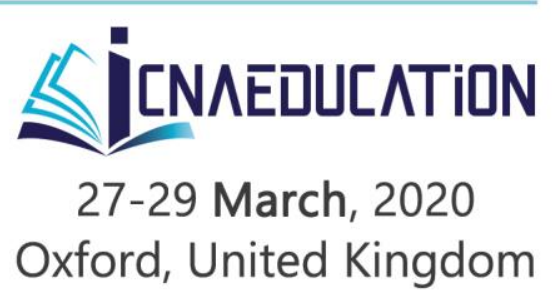

and better if apps for exchanging text messages, photos, videos and voice recordings were used more often - text messaging, Viber, WhatsApp groups. The above-mentioned ways of communication make the visibility of published data possible at any given time, they are simple to use and affordable both for parents and preschool teachers. The content published in social media, which is used for communication with parents, should be of high quality, carefully thought out, and always directed at protecting the privacy of the child and his/her parent.

\section{Conclusion}

Partnership is a harmonious relationship between parents and preschool teachers who share the same task, which is children's upbringing. At the same time, it is a process in which all participants have the equal opportunities to learn and develop their personal and professional competencies. Although preschool teachers recognize the importance of partnership, there are certain barriers that deflect the establishment of successful partnership relationships. Based on the given responses, we can conclude that the barriers are less present if parents are involved in the kindergarten life more often, and the benefits are manifold, primarily for the child, but also for the parents/family and preschool teachers. Given all that, by strengthening the preschool teachers' competencies, it is possible to improve the existing forms of cooperation between education institutions and parents into a partnership, which is in the children's best interest. The Bologna Process has made various changes in the Croatian higher education system, and the majority of them are seen in the teaching syllabus and curriculum. It is apparent how higher education trends change, so the greater emphasis is put on practical work to prepare students for their future jobs. Although the initial education of preschool teachers recognizes the widening of the existing programs with contents related to cooperation with families, these education forms are still not sufficient to develop the competencies necessary for cooperation with parents. Thus, the ways of widening the initial education with practical exercises for establishing partnership between education institutions and families should be though of. With that in mind, it is possible to conclude that innovative educational strategies are sought on the initial education level, as well as the higher level of action, effectiveness and quality of education institutions on all levels, in order to respond to the challenges and the authentic context in which partnership occurs. In other words, it is of the utmost importance to connect the initial education with practice, and continuously contribute to the partnership between families and education institutions, since that is an important and challenging area which calls for educated professionals. Although the self-assessment of competency depends also on the factors not included in this research, the current paper's scientific contribution is in the theoretical elaboration of preschool teachers' competencies for inclusive practice and partnership with parents, based on the recent scientific literature. 


\section{LCNAEDUCATION \\ 27-29 March, 2020 \\ Oxford, United Kingdom}

\section{References}

[1] Acedo, C. (2008). Inclusive education: Pushing the boundaries, Prospects, vol. 38 (1), pp. 5-13.

[2] Avramidis, E., Bayliss, P. and Burden, R. (2000). A Survey into Mainstream Teachers' Attitudes Towards the Inclusion of Children with Special Educational Needs in the Ordinary School in one Local Education Authority, Educational Psychology, vol. 20 (2), pp. 192-211.

[3] Cankar, F., Deutsch, T. and Kolar, M. (2009). Teachers and parents - partners with different expectations, International Journal about Parents in Education, vol. 3 (1), pp. $15-28$.

[4] Hornby, G. (2011). Parental Involvement in Childhood Education: Building Effective School-Family Partnerships. New York: Springer.

[5] DCSF, Department of Children, Schools and Families. (2008). Parents Partners in Early Learning, Nottingham, UK: HMSO.

[6] Deslandes, R., Barma, S. and Morin, L. (2015). Understanding complex relationships between teachers and parents, International Journal of Parents in Education, vol. 9 (1), pp. 131-144.

[7] Dunlap, G. and Fox, L. (2007). Parent-professional partnerships: A valuable context for addressing challenging behaviors, International Journal of Disability, Development and Education, vol. 54 (3), p. 273-285.

[8] Epstein, J. L. (2011). School, family, and community partnerships: preparing educators and improving schools. Boulder, CO: Westview Press.

[9] Jurčević Lozančić, A. (2016). Socijalne kompetencije u ranome djetinjstvu. Zagreb: Učiteljski fakultet Sveučilišta u Zagrebu.

[10] Jurčević Lozančić, A., Basta, S. and Šerbetar, I. (2019). Teachers' Attitudes Towards Collaboration with Parents: Development and Evaluation of the Questionnaire, Sodobna pedagogika. Journal of Contemporary Educational Studies, vol. 70 (4), pp. 136-150.

[11] Keyser, J. (2006). From Parents to Partners: Building a Family - Centered Early Childhood Program. Washington: Redleaf Press, NAEYC.

[12] Lee, J. and Bowen, N. (2006). Parent involvement, cultural capital, and the achievement gap among elementary school children, American Educational Research Journal, vol. 43 (2), pp. 193-218.

[13] Ljubetić, M. (2014). Od suradnje do partnerstva obitelji, odgojno-obrazovne ustanove i zajednice. Zagreb: Element.

[14] Maleš, D., Kušević, B. and Širanović, A. (2014). Child Participation in Family-School Cooperation, Center for Educational Policy Studies Journal, vol. 4 (1), pp. 121-136. 
[15] McWayne, C. and Owsianik, M. (2004). Parent Involvement and the social and academic competencies of urban kindergarten children in Harvard Family Research Project. Retrieved from www.hfrp.org/publications-resources/publicationsseries/familyinvolvement-research-digests/parent-involvement-and-the-social-andacademiccompetenciesof-urban-kindergarten-children (accessed on 10 April 2019).

[16] Mitchel, L. C. and Hegde, A. V. (2007). Beliefs and practices of In-service preschool teachers in inclusive settings: Implications for personnel preparation, Journal of Early Childhood Teacher Education, vol. 28, pp. 353-366.

[17] Nacionalni kurikulum za rani i predškolski odgoj i obrazovanje (2014). Zagreb: Republika Hrvatska, Ministarstvo znanosti, obrazovanja i sporta.

[18] Preston, J. P. (2009). Educational reform via school councils: Saskatchewan's School Community Councils as compared to an international precedent, Canadian and International Education, vol. 38 (1), pp. 29-44.

[19] Odom, S. L., Buysse, V. and Soukakou, E. (2011). Inclusion for young children with disabilities: A quarter century of research perspectives, Journal of Early Intervention, vol. 33 (4), p. 344-356.

[20] Özyürek, A. (2012). The effect of parental acceptance in the success of inclusion in preschool education, The International Journal of Social Sciences, vol. 3 (1), pp. 1-10.

[21] Preston, J. P. (2011). Influencing community involvement in school: A school community council, McGill Journal of Education, vol. 46 (2), pp. 197-212.

[22] Ranson S., Martin, J. and Vincent, C. (2004). Storming parents, schools and communicative inaction, British Journal of Sociology of Education, vol. 25 (3), pp. 259-274.

[23] Ressler, R. W., Smith, C. and Crosnoe, R. (2017). Mothers' union statuses and their involvement in young children's schooling, Journal of Marriage and Family, vol. 79 (1), pp. 94-109.

[24] Visković, I. and Višnjić Jevtić, A. (2017). Development of professional teacher competences for cooperation with parents, Early Child Development and Care, vol. 187 (10), pp. 1569-1582.

[25] Živčić-Bečirević, I. and Smojver-Ažić, S. (2005) Izvori stresa na poslu odgojitelja u dječjim vrtićima, Psihologijske teme, vol. 14, pp. 493-499.

[26] Ward, U. (2013). Working with Parents in the Early Years. London: SAGE.

[27] Whalley, M. (2007). Involving parents in children's learning, (2nd ed.), London: Paul Chapman Press

[28] Wheeler, H. and Connor, J. (2006). Parents Early Years and Learning, (2nd ed.), London: National Childrens Bureau.

[29] Westergard, E. (2013). Teacher Competencies and Parental Cooperation, International Journal about Parents in Education, vol. 7 (2), pp. 91-99. 


\section{$2^{\text {nd }}$ International Conference on \\ New Approaches in EDUCATION}

\section{SILNAEDULATION \\ 27-29 March, 2020 \\ Oxford, United Kingdom}

[30] Winton, P. J., Brotherson, M. J. and Summers, J. A. (2008). Learning from the field of early intervention about partnering with families. In M. M. Cornish (Ed.), Promising practices for partnering with families in the early years (pp. 21-40). Charlotte, NC: Information Age. 